\title{
KOMPOSISI KIMIA BABY FISH NILA LARASATI (Oreochromis niloticus) PADA BERBAGAI UMUR PANEN DALAM SISTEM AKUAPONIK
}

\author{
La Ode Abdul Rajab Nadia ${ }^{1^{*}}$, Laode Muhamad Hazairin Nadia ${ }^{2}$, \\ Rosmawati ${ }^{3}$, Wa Ode Piliana ${ }^{3}$
}
'Jurusan Manajemen Sumberdaya Perairan, Fakultas Perikanan dan Ilmu Kelautan Universitas Halu Oleo ${ }^{2} J u r u s a n$ Teknologi Hasil Perikanan, Fakultas Perikanan dan Ilmu Kelautan Universitas Halu Oleo
${ }^{3}$ Jurusan Agrobisnis Perikanan, Fakultas Perikanan dan Ilmu Kelautan Universitas Halu Oleo
Kampus Hijau Bumi Tridharma Anduonohu, Jalan H.E.A Mokodompit, Kendari 93232 Sulawesi Tenggara
*Korespondensi: rajabnadiauho@gmail.com
Diterima: 22 September 2019/Disetujui: 01 Mei 2020

Cara sitasi: Nadia LOAR, Nadia LMH, Rosmawati, Piliana WO. 2020. Komposisi kimia baby fish nila larasati (Oreochromis niloticus) pada berbagai umur panen dalam sistem akuaponik. Jurnal Pengolahan Hasil Perikanan Indonesia. 23(2): 215-224

\begin{abstract}
Abstrak
Baby fish nila larasati digemari oleh masyarakat dalam bentuk goreng dan crispy, tetapi informasi komposisi gizi mengenai baby fish nila larasati segar masih sedikit. Penelitian ini bertujuan untuk menentukan komposisi kimia dan asam lemak baby fish nila larasati pada umur panen yang berbeda dalam sistem akuaponik. Metode yang digunakan pola faktorial dengan satu faktor yaitu perlakuan perbedaan umur panen (14 hari, 21 hari, 28 hari, dan 35 hari). Parameter yang diamati yaitu morfometrik (bobot tubuh, panjang total, dan tinggi badan), komposisi kimia, dan asam lemak. Hasil penelitian menunjukkan bahwa pertambahan bobot ikan memengaruhi komposisi kimia. Hasil analisis statistik proksimat baby fish nila larasati menunjukkan perbedaan yang signifikan terhadap umur panen $(p<0,05)$. Saturated fatty acid (SAFA) dan polyunsaturated fatty acid (PUFA) tertinggi yaitu palmitat (C6:0) dan linoleat (C18:2n6) pada umur panen 14 hari.
\end{abstract}

Kata kunci: asam lemak, komposisi kimia, morfometrik, nila larasati, umur panen

\section{Chemical Composition of Baby Fish Tilapia (Oreochromis niloticus) Harvested in Different Periods Reared Under Aquaponic System}

\begin{abstract}
Baby fish tilapia is mostly consumed by society in fried the fish and crispy forms, but the information on the nutritional composition of the fish is limited. The objective of the present study was to evaluate the chemical composition and fatty acids of baby fish tilapia harvested in different periods reared under aquaponic system. The research was conducted in factorial design with single factor namely different harvesting periods (14 days, 21 days, 28 days, and 35 days). The parameters measured were morphometric (body weight, total length and body length), chemical composition, and fatty acids. The results showed that the body weight affected the chemical composition. Statistical analysis showed that the proximate analysis was significantly different among the treatments $(p<0.05)$. The highest saturated fatty acid (SAFA) and polyunsaturated fatty acid (PUFA) was palmitate (C6:0) dan linoleat (C18:2n6) respectively obtained at fish harvested in 14 days.
\end{abstract}

Keywords: chemical composition, fatty acid, harvesting period, morfometric, tilapia

\section{PENDAHULUAN}

Perkembangan teknologi budi daya ikan air tawar di Indonesia begitu cepat. Salah satu teknologi yang saat ini dikembangkan adalah akuaponik. Teknologi tersebut adalah integrasi budi daya tanaman dan budi daya ikan. Akar tanaman berfungsi sebagai biofilter yang mampu menurunkan kandungan amonia air kolam. Amonia yang dihasilkan dari sisa pakan/feses ikan di kolam budi daya sebagai salah satu unsur hara tanaman (Putra et al. 2011). Budi daya ikan dengan 
akuaponik tergolong zero waste dan organik. Model budi daya tersebut dapat digunakan untuk memelihara berbagai jenis ikan, termasuk ikan nila larasati.

Ikan nila larasati (Oreochromis niloticus) adalah salah satu strain baru ikan nila dengan karakter gen tumbuh cepat. Ikan tersebut merupakan hasil persilangan ikan nila pandu dan kunti yang dapat menghasilkan ikan nila hibrida berkualitas unggul. Djunaedi et al. (2016) mengemukakan bahwa O. niloticus mempunyai beberapa kelebihan yaitu pertumbuhannya cepat, dapat mencerna makanan dengan efisien, tahan terhadap penyakit dan cepat beradaptasi pada media pemeliharaan.

Ikan nila larasati umumnya dikonsumsi dalam ukuran dewasa. Namun, tren yang ada saat ini di masyarakat Indonesia bahwa ikan nila juga dikonsumsi dalam ukuran kecil yang biasa dikenal dengan nama baby fish nila. Baby fish nila diolah dalam bentuk goreng dan crispy. Velasquez et al. (2016) menyampaikan bahwa ikan dalam tahap juvenil berukuran panjang berkisar antara $3-4,5 \mathrm{~cm}$. Ukuran tersebut memiliki kandungan gizi yang baik untuk dikonsumsi.

Asam lemak (fatty acid) merupakan salah satu kandungan gizi yang terdapat pada ikan. Beberapa penelitian terkait asam lemak menunjukkan bahwa ikan banyak mengandung asam lemak yang sangat bermanfaat untuk kesehatan (Jacoeb et al. 2020; Suseno et al. 2020; Pratama et al. 2018; Afifudin et al. 2018; Abdullah et al. 2017; Nurjanah et al. 2015; Abdullah et al. 2015; Jacoeb et al. 2015; Abdullah et al. 2013). Asam lemak terdiri atas saturated fatty acid (SAFA) dan unsaturated fatty acid (UFA). UFA yang banyak terdapat pada ikan adalah eicosapentaenoic acid (EPA), docosahexaenoic acid (DHA), linoleat serta linolenat. Asam lemak ini banyak dibutuhkan oleh manusia karena memiliki beberapa manfaat yaitu mencegah dan mengobati penyakit kardiovaskuler, mendorong perkembangan otak pada bayi, dan menurunkan kadar trigliserida dalam darah (Osman et al. 2001).

Kandungan gizi pada ikan dipengaruhi beberapa faktor di antaranya spesies, ukuran, habitat serta pakan yang digunakan (Isa et al.2015).Hasil penelitian yang dilakukan Ramlah et al. (2016) bahwa kandungan protein dan lemak ikan nila yang habitatnya di danau yaitu $16,79 \%$ dan $0,18 \%$. Edison (2010) menyatakan bahwa kandungan asam lemak ikan nila yang dipelihara selama 6 bulan di karamba mempunyai nilai SAFA palmitat paling tinggi sebesar $35,48 \%$. Pemanfaatan baby fish nila larasati belum didukung dengan adanya informasi tentang komposisi kimia dan kandungan asam lemak terutama hasil budidaya dengan sistem akuaponik, sehingga perlu dilakukan penelitian lebih lanjut. Tujuan penelitian ini yaitu menentukan komposisi kimia dan asam lemak baby fish nila larasati pada umur panen berbeda dalam sistem akuaponik.

\section{BAHAN DAN METODE Bahan dan Alat}

Bahan utama yang digunakan adalah ikan nila larasati (O. niloticus) yang dibudidayakan dengan sistem akuaponik di kolam air tawar FPIK-UHO. Bahan lain yang digunakan dalam penelitian adalah akuades, asam sulfat (Merck), natrium hidroksida (Merck), asam klorida 0,1 N (Merck), asam borat (Merck), pelarut heksana, natrium hidroksida 0,5 N (Merck), boron triflorida (Merck), natrium klorida (Merck), heksana (Merck), dan natrium sulfat anhidrat (Merck).

Alat penelitian ini adalah alat bedah, cool box, penggaris, cawan porselen, tabung reaksi $50 \mathrm{~mL}$ dan $125 \mathrm{~mL}$, oven (Memmert UN260, Jerman), desikator (Duran-part bowl, Jerman), tanur, kompor listrik (Maspion S-300, Indonesia), alat gelas, tabung kjeldahl, tabung soxhlet, labu lemak, timbangan analitik (Fujitsu FSR-B, Jepang), kromatografi gas (Hitachi 263-50 GC, Jepang), dan water bath (model SWB 30 merck B-ONE, China).

\section{Metode Penelitian}

Penelitian ini terdiri dari beberapa tahapan, yaitu pengukuran morfometrik (meliputi panjang total, tinggi badan, dan berat ikan), preparasi sampel, analisis proksimat, dan analisis asam lemak. 


\section{Pengukuran morfometrik}

Pengukuran morfometrik dilakukan dengan mengambil sampel secara acak sebanyak 10 ekor setiap panen. Pengukuran sampel meliputi panjang total, tinggibadan dan berat ikan per ekor. Panjang total diukur dari anterior mulut sampai posterior sirip kaudal. Tinggi badan diukur dari jarak tertinggi antara dorsal dan ventral. Pengukuran panjang total dan tinggi badan menggunakan penggaris dengan satuan milimeter. Berat ikan diukur menggunakan neraca digital

\section{Preparasi sampel}

Sampel yang telah dipanen, dilakukan pemberokan terlebih dahulu selama 24 jam dalam akuarium sebelum dipreparasi. Pemberokan bertujuan untuk menghilangkan sisa makanan dan feses di dalam sistem pencernaan. Preparasi yang dilakukan yaitu dengan memisahkan benda asing dan mencuci bersih baby fish nila larasati. Sampel dengan umur panen 14 hari, 21 hari, 28 hari, dan 35 hari dianalisis proksimat dan asam lemak.

\section{Analisis proksimat}

Analisis proksimat yang dilakukan mengacu pada metode AOAC (2005). Analisis proksimat dilakukan terhadap baby fish nila larasati meliputi analisis kadar air, kadar abu, kadar protein, dan kadar lemak.

\section{Analisis kadar air}

Pengukuran kadar air baby fish nila larasati menggunakan metode oven. Cawan yang digunakan dikeringkan dalam oven pada suhu $100-105^{\circ} \mathrm{C}$ selama 30 menit atau sampai didapat berat tetap. Selanjutnya didinginkan dalam desikator selama 30 menit dan ditimbang. Sampel baby fish nila larasati ditimbang sebanyak $5 \mathrm{~g}$ (B1) dalam cawan tersebut lalu dikeringkan dalam oven pada suhu $100-105^{\circ} \mathrm{C}$ sampai tercapai berat tetap (8-12 jam). Selanjutnya sampel didinginkan dalam desikator selama 30 menit lalu ditimbang (B2).

\section{Analisis kadar abu}

Penentuan kadar abu baby fish nila larasati menggunakan metode pengabuan kering (dry ashing). Cawan yang digunakan dikeringkan terlebih dahulu 30 menit dalam oven pada suhu $100-105^{\circ} \mathrm{C}$. Kemudian didinginkan dalam desikator selama 30 menit lalu ditimbang (B1). Sampel baby fish nila larasati sebanyak 5 g dimasukkan dalam cawan yang telah diketahui beratnya, selanjutnya dibakar di atas bunsen atau kompor listrik sampai tidak berasap, dimasukkan dalam tanur pengabuan, kemudian dibakar pada suhu $400^{\circ} \mathrm{C}$ sampai didapat abu berwarna abu-abu atau sampel beratnya tetap. Tahap selanjutnya suhu tanur dinaikkan sampai $550^{\circ} \mathrm{C}$ selama $12-24$ jam. Sampel didinginkan dalam desikator selama 30 menit lalu ditimbang (B2).

\section{Analisis kadar protein}

Sampel baby fish nila larasati dihaluskan dan ditimbang 0,2 g, kemudian dipindahkan ke dalam labu kjeldahl $30 \mathrm{~mL}$. Sampel tersebut ditambahkan 1 spatula katalisator $\mathrm{Na}_{2} \mathrm{SO}_{4}-\mathrm{HgO}(20: 1)$ dan $2 \mathrm{~mL} \mathrm{H}_{2} \mathrm{SO}_{4}$. Sampel dididihkan selama 2,5 jam sampai cairan menjadi jernih. Kemudian dinginkan dan ditambahkan $15 \mathrm{~mL}$ akuades dan $10 \mathrm{~mL}$ larutan $\mathrm{NaOH}$ ke dalam tabung destilasi. Enlenmeyer $125 \mathrm{~mL}$ yang berisi $10 \mathrm{~mL} \mathrm{H}_{2} \mathrm{BO}_{4}$ diletakkan di bawah kondensor. Didestilasi sampai destilat berwarna kehijauan dalam erlenmeyer, dititrasi dengan larutan $\mathrm{HCl}$ 0,2 N sampai warna menjadi merah jambu. Volume $\mathrm{HCl}$ yang digunakan dicatat.

\section{Analisis asam lemak}

Lemak diekstraksi menggunakan $3 \mathrm{~g}$ sampel baby fish nila larasatidengan campuran kloroform:metanol (2:1), selanjutnya metil ester asam lemak disiapkan menggunakan boron trifluorida sebagai katalis. Kromatografi gas dilengkapi dengan detektor ionisasi nyala dan kolom kapiler ( $\mathrm{p}=60 \mathrm{~m}, \emptyset=0,25 \mathrm{~mm}$ ). Suhu kolom diprogram pada $125^{\circ} \mathrm{C}$ selama 5 menit, kemudian dinaikkan menjadi $225^{\circ} \mathrm{C}$ selama 7 menit. Suhu detektor dan injektor, masing-masing $200^{\circ} \mathrm{C}$ dan $240^{\circ} \mathrm{C}$. Nitrogen digunakan sebagai gas pembawa dengan laju alir $20 \mathrm{~mL} / \mathrm{menit}$. Laju alir untuk hidrogen dan udara, masing-masing adalah $30 \mathrm{~mL} /$ menit dan 200-250 mL/menit. Profil asam lemak ditentukan menggunakan kromatografi gas sedangkan penyiapan metil ester mengacu pada metode AOAC (2005). Komposisi asam lemak diidentifikasi dan dihitung dengan 
membandingkan puncak sampel dan standar metil ester asam lemak (FAME Mix 37 Supelco).

\section{Rancangan percobaan}

Desain penelitian yang digunakan adalah rancangan acak lengkap (RAL) dengan perlakuan perbedaan umur panen (14 hari, 21 hari, 28 hari, dan 35 hari). Penelitian ini menggunakan 10 kali ulangan (morfometrik) dan 3 kali ulangan (analisis proksimat dan asam lemak).

\section{Rancangan percobaan}

Data morfometrik, proksimat, dan asam lemak dianalisis menggunakan analisis ragam (ANOVA) perangkat lunak Statistical Package for Social Science (SPSS) 15 dan ketika beda nyata, maka dilanjutkan dengan uji lanjut duncan's multiple range test (DMRT) pada taraf kepercayaan 95\% (Steel dan Torrie 1993).

\section{HASIL DAN PEMBAHASAN Karakteristik Morfometrik Ikan}

Baby fish nila larasati pada umur panen 35 hari memiliki nilai morfometrik terbesar yaitu bobot $5,41 \mathrm{~g}$, panjang total $7,20 \mathrm{~cm}$ dan tinggi badan $2 \mathrm{~cm}$. Sedangkan nilai morfometrik terkecil pada umur panen 14 hari yaitu bobot $0,27 \mathrm{~g}$, panjang total $2,20 \mathrm{~cm}$ dan tinggi badan $0,61 \mathrm{~cm}$ (Table 1).

Table 1 menunjukkan bahwa terjadi penambahan bobot, panjang total, dan tinggi badan baby fish nila larasati pada setiap umur panen. Hal tersebut terlihat pada kisaran bobot $0,27 \pm 0,11-5,41 \pm 0,11$, kisaran panjang total 2,20 $\pm 0,01-7,20 \pm 0,01$ dan kisaran tinggi tubuh $0,61 \pm 0,01-2,21 \pm 0,01$. Penambahan ukuran tubuh terjadi karena adanya efisiensi penggunaan pakan dan kualitas air sangat baik. Faktor kualitas air dipengaruhi oleh terjadinya nitrifikasi perairan dengan sistem biofilter dalam akuaponik. Menurut Widyastuti (2008) bahwa biofilter akar tanaman dalam akuaponik mampu mereduksi amonia menjadi nitrat dengan bantuan oksigen dan bakteri. Amonia yang dihasilkan melalui proses osmoregulasi, feses dan dari urin dapat diatasi dengan biofiltrasi akuaponik.

Pakan yang diberikan pada saat pemeliharaan merupakan faktor penting dalam pertumbuhan. Pertumbuhan ikan membutuhkan kadar protein tinggi, sehingga dperlukan pakan tambahan berupa pakan buatan sebagai sumber protein untuk mendukung pertumbuhan ikan yang lebih baik. Pakan tambahan yang diberikan berupa pelet. Kandungan protein pada pelet ikan berkisar antara 20 - 25\% (Mulyadi et al. 2010). Serajuddin et al. (2013) melaporkan juga bahwa selain pakan, kondisi lingkungan di antaranya habitat, suhu, dan oksigen terlarut pada perairan, juga memengaruhi pertumbuhan ikan. Selama pemeliharaan di kolam akuaponik, nilai suhu berkisar 25$30,4^{\circ} \mathrm{C}, \mathrm{pH}$ berkisar 6,5-7,8, dan DO berkisar 5,4-6,3. Kondisi lingkungan tersebut sangat mendukung untuk pertumbuhan nila larasati.

\section{Komposisi Kimia Ikan}

Analisis proksimat penelitian ini dilakukan terhadap baby fish nila larasati pada umur panen 14 - 35 hari. Hasil statistik proksimat menunjukkan terdapat perbedaan yang signifikan terhadap umur panen (Table 2).

\section{Kadar air}

Kadar air baby fish nila larasati pada umur panen berbeda disajikan pada Table 2 . Kadar air tertinggi terdapat pada umur panen

Table 1 Morphometrics of baby fish tilapia larasati

\begin{tabular}{lcccc}
\hline \multirow{2}{*}{ Parameter } & 14 & 21 & 28 & 35 \\
\cline { 2 - 5 } & $0.27 \pm 0.11^{\mathrm{a}}$ & $0.73 \pm 0,01^{\mathrm{b}}$ & $3.34 \pm 0,43^{\mathrm{c}}$ & $5.41 \pm 0.11^{\mathrm{d}}$ \\
\hline Weight $(\mathrm{g})$ & $2.20 \pm 0.01^{\mathrm{a}}$ & $3.58 \pm 0,01^{\mathrm{b}}$ & $5.64 \pm 0,28^{\mathrm{c}}$ & $7.20 \pm 0.01^{\mathrm{d}}$ \\
Total length $(\mathrm{cm})$ & & & \\
Height $(\mathrm{cm})$ & $0.61 \pm 0.01^{\mathrm{a}}$ & $1.10 \pm 0,01^{\mathrm{b}}$ & $1.40 \pm 0,05^{\mathrm{c}}$ & $2.21 \pm 0.01^{\mathrm{d}}$ \\
\hline
\end{tabular}

Note: different superscript letters in the same row show the significant differences $(p<0.05)$ 
Table 2 Chemical composition of baby fish tilapia

\begin{tabular}{lcccc}
\hline \multirow{2}{*}{$\begin{array}{c}\text { Chemical } \\
\text { composition (\%) }\end{array}$} & 14 days & 21 days & 28 days & 35 days \\
\cline { 2 - 5 } & $80.68 \pm 0.21^{\text {cd }}$ & $79.69 \pm 0.60^{\mathrm{a}}$ & $80.16 \pm 0.16^{\mathrm{ab}}$ & $80.33 \pm 0.62^{\mathrm{bc}}$ \\
Moisture & $1.55 \pm 0.11^{\mathrm{a}}$ & $2.63 \pm 0.10^{\mathrm{b}}$ & $2.86 \pm 0.06^{\mathrm{c}}$ & $2.99 \pm 0.15^{\mathrm{cd}}$ \\
Ash & $13.13 \pm 0.05^{\mathrm{a}}$ & $13.29 \pm 0.38^{\mathrm{b}}$ & $13.50 \pm 0.49^{\mathrm{c}}$ & $13.84 \pm 0.07^{\mathrm{d}}$ \\
Protein & $2.56 \pm 0.05^{\mathrm{a}}$ & $2.41 \pm 0.05^{\mathrm{b}}$ & $2.03 \mathrm{c} \pm 0.05 \mathrm{c}$ & $1.94 \pm 0.05^{\mathrm{d}}$ \\
\hline
\end{tabular}

Note: different superscript letters in the same row show the significant differences $(\mathrm{P}<0.05)$

14 hari, yaitu $80,68 \%$, sedangkan kadar air terendah terdapat pada umur panen 21 hari yaitu $79,69 \%$.

Sanchez et al. (2012) melaporkan bahwa kadar air yang terdapat pada ikan nila yaitu $72-80 \%$. Ayas dan Ozugul (2011) menyatakan bahwa spesies, umur, kondisi lingkungan dan kesegaran ikan dapat memengaruhi kandungan air pada ikan.

\section{Kadar abu}

Kadar abu tertinggi terdapat pada umur panen 35 hariyaitu 2,99\%. Kadar abu perlakuan umur panen 14-35 hari cenderung lebih tinggi jika dibandingkan dengan penelitian Chaijan (2011) yaitu 0,69\% (nila dewasa). Hal ini diduga karena umur 14-35 hari terjadinya pembentukan tulang. Rasmussen dan Ostenfeld (2000) mengemukakan bahwa kadar abu yang tinggi pada baby fish akibat tejadinya percepatan pertumbuhan tulang, sedangkan ikan dewasa terjadi percepatan pertumbuhan jaringan lainnya daripada pertumbuhan tulang.

\section{Kadar protein}

Table 2 menunjukkan kadar protein baby fish nila larasati pada keempat umur panen saling berbeda $(p<0,05)$. Perlakuan umur panen 14 hari sebesar 13,13\%, 21 hari sebesar 13,29\%, 28 hari sebesar 13,50\%, dan 35 hari sebesar 13,84\%. Kadar protein baby fish nila larasati mengalami peningkatan pada setiap umur panen. Hal tersebut terjadi karena adanya penambahan bobot tubuh ikan pada setiap umur panen yang berpengaruh pada meningkatnya kandungan protein nila larasati. Hal ini sesuai dengan pernyataan Job et al. (2015) bahwa kandungan protein ikan meningkat secara perlahan atau kurang lebih tetap bersamaan dengan meningkatnya berat tubuh ikan. Protein yang terkandung pada ikan dipengaruhi oleh beberapa faktor di antaranya kandungan protein yang terdapat pada pakan, kecernaan ikan pada jenis pakan yang diberikan, spesies ikan dan morfometrik (bobot, panjang total dan tinggi ikan) (Olopade et al. 2016).

\section{Kadar lemak}

Kadar lemak baby fish nila larasati berdasarkan perlakuan umur panen saling berbeda $(p<0,05)$. Table 2 menunjukkan kadar lemak tertinggi pada umur panen 14 hari yaitu $2,56 \%$ dan yang terendah pada umur panen 35 hari sebesar 1,94\%. Hasil tersebut menunjukan bahwa kandungan lemak baby fish nila larasati tergolong rendah. Menurut Justi et al. (2003) bahwa ikan nila termasuk golongan ikan yang mengandung kadar lemak yang rendah yaitu $\leq 2,54 \%$.

Kadar lemak baby fish nila larasati pada setiap perlakuan umur panen mengalami penurunan diduga karena adanya perbedaan umur panen. Selain itu, perubahan nilai asam lemak selama pertumbuhan sebanding dengan perubahan kadar proteinnya. Hal tersebut sesuai dengan penelitian Viera et al. (2012) bahwa kandungan protein yang meningkat di dalam tubuh ikan maka kadar lemak akan menurun. Selain itu, kandungan lemak yang terdapat pada ikan cenderung meningkat seiring tejadinya peningkatan ukuran ikan (Alemu et al. 2013). Ikan menggunakan energi yang terdapat pada lemak lebih besar dalam proses pertumbuhannya, sehingga mengakibatkan pengurangan jumlah lemak yang tersimpan pada tubuh ikan (Ozogul dan Ozogul 2007). 
Peningkatan Kandungan lemak pada ikan bukan hanya dipengaruhi oleh spesies ikan tetapi juga dipengaruhi oleh faktor lainnya seperti feeding habit serta pakan yang diberikan (pakan alami dan buatan). Selain itu, lingkungan perairan tempat di mana ikan tumbuh dan berkembang juga berpengaruh terhadap kandungan lemak pada ikan (Oesman et al. 2007).

\section{Asam lemak}

Asam lemak yang terdeteksi yaitu 4 jenis SAFA, 1 jenis MUFA, dan 3 jenis PUFA. Analisis asam lemak baby fish nila larasati berpengaruh nyata terhadap perlakuan umur panen $(\mathrm{P}<0,05)$. Komposisi asam lemak baby fish nila larasati pada penelitian ini disajikan pada Table 3.

Table 3 menunjukkan adanya asam lemak yang tidak teridentifikasi yaitu pada umur panen 14 hari sebesar 8,71\%, 21 hari sebesar 14,87\%, 28 hari sebesar 22,68\%, dan 35 hari sebesar $37,46 \%$. Hal ini diduga dipengaruhi penggunaan metode soxhlet untuk ekstraksi lemak. Ozogul et al. (2012) menerangkan bahwa penggunaan metode soxhlet kurang efisien digunakan dalam mengekstrak biota perairan dan kurang mampu mencegah kehilangan PUFA yang diakibatkan terjadinya oksidasi lemak dibandingkan dengan penggunaan metode ekstraksi lainnya seperti metode bligh dan dyer.

Total asam lemak pada umur panen 28 hari sebesar 77,32\% dan hasilnya tidak berbeda jauh dengan hasil penelitian De Castro et al. (2007) sebesar 73,6\% (Table 3). Faktor-faktor yang memengaruhi kandungan asam lemak ikan yaitu suhu air, waktu panen, dan jenis pakan yang diberikan. Penurunan total asam lemak pada setiap umur panen diduga karena lemak dipakai untuk pertumbuhan dan jenis makanan yang dikonsumsi serta dipengaruhi oleh organ dalam yang belum sempurna. Mokoginta et al. (2003) menyatakan bahwa dalam pertumbuhannya, ikan membutuhkan linoleat serta linolenat yang diperoleh dari pakan yang diberikan untuk pertumbuhan dan meningkatkan kelangsungan hidup. Selain itu, Muhamad dan Mohamad (2012) menjelaskan bahwa makanan yang dikonsumsi ikan memengaruhi keberadaan asam lemak ikan.

\section{Saturated fatty acid (SAFA)}

Saturated fatty acid yang terdeteksi pada baby fish nila larasati terdiri dari empat jenis yaitu laurat, miristat, palmitat, dan stearat.

Table 3 Fatty acids compositions of baby fish tilapia larasati

\begin{tabular}{lrrrrr}
\hline \multirow{2}{*}{ Fatty Acid } & \multicolumn{4}{c}{ Age (days) } & \multicolumn{1}{c}{ De Castro } \\
et al. 2007
\end{tabular}

Note: different superscript letters in the same row show the significant differences $(p<0.05)$ 
Table 3 menunjukkan total SAFA pada keempat umur panen saling berbeda $(p<0,05)$. Baby fish nila larasati dengan umur panen 14 hari sebesar 33,05\%, 21 hari sebesar 32,36\%, 28 hari sebesar $23,3 \%$, dan 35 hari sebesar $25,25 \%$.

Jenis SAFA yang paling banyak teridentifikasi yaitu palmitat (C16:0). Jumlah palmitat pada lemak baby fish nila larasati dengan umur panen panen 14 hari sebesar 24,39\%, 21 hari sebesar 21,42\%, 28 hari sebesar 19,35\%, dan 35 hari sebesar 20,42\%. Penelitian Justi et al. (2003) menunjukkan bahwa palmitat pada umur panen 30 hari sebesar 16,60\%, maka umur panen 28 hari hasilnya masih lebih tinggi. Tingginya asam palmitat pada baby fish ikan nila sesuai dengan pernyataan Osman et al. (2007) bahwa palmitat merupakan SAFA yang paling banyak terdapat pada lemak ikan yaitu $15-50 \%$ dari seluruh asam lemak.

\section{Monounsaturated fatty acid (MUFA)}

Monounsaturated fatty acid yang terdeteksi pada baby fish nila larasati yaitu asam oleat (C18:1n9). Table 3 menunjukkan asam oleat pada keempat umur panen saling berbeda $(p<0,05)$. Total MUFA pada umur 14 hari sebesar $27,46 \%, 21$ hari sebesar $28,26 \%$, 28 hari sebesar $24,41 \%$, dan 35 hari sebesar $16,53 \%$. Jika dibandingkan dengan hasil penelitian De Castro et al. (2007) pada ikan nila dewasa, maka oleat baby fish nila pada umur 28 hari hasilnya tidak jauh berbeda. Oleat merupakan salah satu MUFA yang memiliki nilai tertinggi di antara asam lemak lainnya yang terdeteksi. Ozugul dan Ozugul (2007) menerangkan bahwa oleat merupakan fatty acid paling banyak dalam MUFA yaitu 52-79\%. Salimon dan Rahman (2008) melaporkan bahwa asam oleat merupakan fatty acid yang paling banyak pada ikan air tawar.

\section{Polyunsaturated fatty acid (PUFA)}

Polyunsaturated fatty acid yang terdeteksi pada baby fish nila larasati yaitu linoleat, linolenat, dan arakidonat. Table 3 menunjukkan total PUFA pada keempat umur panen saling berbeda $(p<0,05)$. Total PUFA pada umur panen 14 hari sebesar 30,78\%, 21 hari sebesar 24,51\%, 28 hari sebesar
29,18\%, dan 35 hari sebesar 20,68\%. Linoleat merupakan asam lemak paling dominan pada PUFA. Kandungan linoleat pada umur panen 14, 21, 28, dan 35 hari berturut-turut sebesar $26,38 \%, 21,28 \%, 22,36 \%$, dan 18,38\%. Hasil tersebut lebih tinggi dibanding penelitian De Casto et al. (2007) yang sebesar 4,7\%.

Kandungan linolenat baby fish nila larasati pada umur panen 14 hari, 21 hari, 28 hari, dan 35 hari berturut-turut sebesar 2,51\%, $1,04 \%, 3,75 \%$, dan $1,34 \%$ dan cenderung tidak berbeda jauh dibanding hasil penelitian Justi et al. (2003) sebesar 1,04\%. Ozugul dan Ozugul (2007) mealoprkan bahwa komposisi asam lemak dapat dipengaruhi beberapa faktor yaitu jenis ikan, pakan yang diberikan, umur ikan, habitat, dan morfometrik.

Kandungan arakidonat pada baby fish nila larasati pada umur panen tersebut berturut-turut sebesar 1,89\%, 2,19\%, 3,07\%, dan $0,96 \%$. Arakidonat pada umur panen 28 hari cenderung tidak jauh berbeda dengan hasil penelitian De Casto et al. (2007) yaitu sebesar 4,1\%. Udani dan Barry (2013) menjelaskan bahwa linolenat dan arakidonat dapat mengurangi kekentalan darah tanpa efek pada trombosit serta memiliki efek positif pada lipid darah.

\section{KESIMPULAN}

Pertambahan bobot baby fish nila larasati menunjukkan perbedaan yang signifikan terhadap umur panen $(p>0,05)$. Asam lemak yang terdeteksi yaitu 4 jenis SAFA, 1 jenis MUFA, dan 3 jenis PUFA. Analisis asam lemak dan protein baby fish nila larasati berpengaruh nyata terhadap perlakuan umur panen $(p<0,05)$. Perubahan nilai asam lemak selama pertumbuhan sebanding dengan perubahan kadar proteinnya.

\section{UCAPAN TERIMA KASIH}

Tim penulis menghaturkan terima kasih kepada Kementerian Riset, Teknologi, dan Pendidikan Tinggi (Direktorat Jenderal Penguatan Riset dan Pengembangan), yang telah membiayai kegiatan pengabdian skema Pengembangan Usaha Produk Intelektual Kampus (PPUPIK) Tahun 2019. Terimakasih pula kami sampaikan kepada Bapak Rektor Universitas Halu Oleo dan Dekan FPIK 
Universitas Halu Oleo yang telah banyak berkontribusi terutama dukungan kebijakan dan sharing cost untuk kegiatan PPUPIK.

\section{DAFTAR PUSTAKA}

[AOAC] Association of Official Analytical Chemist. 2005. Official Method of Analysis of the Association of Official Analytical of Chemist. Virginia (US): Published by The Association of Analytical Chemist, inc.

Abdullah A, Nurjanah, Hidayat T, Chairunisah R. 2017. Karalteristik kimiawi kerang tahu, kerang tahu, dan keong macan. Jurnal Teknologi Industri Pangan. 28(10:74-84.

Abdullah A, Nurjanah, Hidayat T, Aji DU. 2015. Fatty acid profile of jellyfish (Aurelia aurita) as a source raw material of aquatic result rich benefit. International Journal of Chemical and Biomolecular Science. 1(1): 12-16

Abdullah A, Nurjanah, Hidayat T, Yusefi Y. 2013. Profil asam amino dan asam lemak kerang bulu (Anadara antiquata). Jurnal Pengolahan Hasil Perikanan Indonesia. 16(2): 159-167.

Afifudin IK, Suseno SH, Jacoeb AM. 2014. Profil asam lemak dan asam amino gonad bulu babi. Jurnal Pengolahan Hasil Perikanan Indonesia. 17(1): 60-70.

Alemu LA, Malese, AY, Gulelat DH. 2013. Effect of endogenous factors on proximate composition of nile tilapia (Oreochromis niloticus L.) fillet from Lake Zeway. American Journal of Research Communication. 1(11): 405-410.

Ayas D, Ozugul Y. 2011. The chemical composition of carapace meat of sexually mature blue crab (Callinectes sapidus, Rathbun 1896) in the mersin bay. Journal Fisheries Sciences. 5(4): 308-316.

Chaijan M. 2011. Physicochemical changes of tilapia (Oreochromis niloticus) muscle during salting. Food Chemistry 129(3): 1201-1210.

De Castro FAF, Sant'ana HMP, Campos FM, Costa NMB, Silva MTC, Salaro AL, Francheschini SCC. 2007. Fatty acid composition of three freshwater fishes under different strorage and cooking process. Food Chemistry. 103(4) : 10801090.

Djunaedi A, Hartati R, Pribadi R, Redjeki S, Astuti RW, Septiarani B. 2016. Pertumbuhan ikan nila larasati (Oreochromis niloticus) di tambak dengan pemberian ransum pakan dan padat penebaran yang berbeda. Jurnal Kelautan Tropis. 19(2):131-142.

Edison. 2010. Komposisi asam lemak ikan nila (Oreochromis niloticus) dan baung (Macromes nemurus) budidaya. Jurnal Pengolahan Hasil Perikanan Indonesia. 8(2): 96-104.

Isa M, Rinidar, Zalia T, Harris A, Sugito, Herrialfian. 2015. Analisis proksimat kadar lemak ikan nila yang diberi suplementasidaun jaloh yang dikombinasi dengan kromium dalam pakan setelah pemaparan stres panas. Jurnal Medika Veterinaria. 1(9): 60-63.

Jacoeb AM, Nurjanah, Hidayat T, Perdiansyah R. 2020. Komposisi kimia dan profil asam lemak ikan layur segar penyimpanan suhu dingin. Jurnal Pengolahan Hasil Perikanan Indonesia. 23(1): 147-157.

Jacoeb AM, Suptijah P, Kristantina WA. 2015. Komposisi asam lemak, kolesterol, dan deskripsi jaringan fillet ikan kakap merah segar dan goreng. Jurnal Pengolahan Hasil Perikanan Indonesia. 18(1): 98-107.

Job BE, Antai EE, Iyang-Etoh AP, Otogo GA, Ezekiel HS. 2015. Proximate composition and mineral contents of cultured and wild tilapia (Oreochromis niloticus) (Pisces: Chiclidae) (Linnaeus, 1758). Pakistan Journal of Nutrition. 14(4): 195-200.

Justi KC, Hayashi C, Visentainer JV, de Souza NE, Matsushita M. (2003). The influence of feed supply time on the fatty acid profile of nile tilapia (Oreochromis niloticus) fed on a diet enriched with n-3 fatty acids. Food Chemisty. 80(4): 489-493.

Mokoginta I, Jusadi D, Pelawi TL. 2003. Pengaruh pemberian Daphnia sp. yang diperkaya dengan sumber lemak yang berbeda terhadap kelangsungan hidup dan pertumbuhan larva ikan nila, 
Oreochromis niloticus. Jurnal Akuakultur Indonesia. 2(1): 7-11.

Muhamad NA, Mohamad J. 2012. Fatty acids composition of selected Malaysian fishes. Sains Malaysiana 41(1): 81-94.

Mulyadi, Usman MT, Suryani. 2010. Pengaruh frekuensi pemberian pakan yang berbeda terhadap pertumbuhan dan kelangsungan hidup benih ikan selais (Ompok hypophthalmus). Berkala Perikanan Terubuk. 38(2): 21-40.

Nurjanah, Suseno SH, Hidayat T, Ekawati Y, Paramudhita P, Arifianto. 2015. Change Composisition chemical of skipjack tuna due to frying process. International Food Research Journal. 2(5): 2093-2102.

Olopade OA, Taiwo IO, Lamidi AA, Awonaike OA. 2016. Proximate composition of nile tilapia (Oreochromis niloticus) (Linnaeus, 1758) and tilapia hybrid (Red Tilapia) from Oyan Lake, Nigeria. Bulletin UASVM Food Science and Technology. 73(1): 19-23.

Osman F, Jaswir I, Khaza’ai H, Hashim R. 2007. Fatty acid profiles of fin fish in Lengkawi Island, Malaysia. Journal Oleo Science. 56(3): 107-113.

Osman H, Suriah AR, Law EC. 2001. Fatty acid composition and cholesterol content of selected marine fish in Malaysian water. Food Chemistry. 73(1): 55-60.

Ozogul Y, Simsek A, Balikci E, Kenar M. 2012. The effects of extraction methods on the contents of fatty acids, especially EPA and DHA in marine lipids. International Journal of Food Sciences and Nutrition. 63(3): 26-31.

Ozugul Y, Ozugul F. 2007. Fatty acid profiles of commercially important fish species from the mediterranean, agean dan black seas. Food Chemistry. 100(4): 1634-1638.

Putra, I., D. D. Setiyanto, dan D. Wahyjuningrum., 2011. Pertumbuhan dan Kelangsungan Hidup Ikan Nila (Oreochromis niloticus) dalam Sistem Resirkulasi. Jurnal perikanan dan kelautan Vol 16(1): Hal 56-63.

Pratama RI, Rostini I, Rochima E. 2018. Profil asam amino, asam lemak dan komponen volatil ikangurame(Osphronemusgouramy) segar dan kukus. Jurnal Pengolahan Hasil Perikanan Indonesia. 21(2): 218-231.

Ramlah E, Soekendarsi Z, Hasyim, Hasan MS. 2016. Perbandingan kandungan gizi ikan nila Oreochromis niloticus asal danau mawang Kabupaten Gowa dan danau Universitas Hasanuddin Kota Makassar. Jurnal Biologi Makassar. 1(1): 39-46.

Rasmussen RS, Ostenfeld TH. 2000. Effect of growth rate on quality traits and feed utilisation of rainbow trout (Oncorhynchus mykiss) and brook trout (Salvelinus fontinalis). Aquaculture. 184(4):327-337.

Salimon J, Rahman NA. 2008. Fatty acid composition of selected farmed and wild freshwater fishes. Sains Malaysiana. 37(2): 149-153.

Sanchez FH, Morales MEA. 2012. Nutritional richness and importance of the consumption of tilapia in the Papaloapan region. Revista Electronica de Veterinaria.13(6): 1-12.

Serajuddin ML, Prasad, Pathak BC. 2013. Comparative study of length-weight relationship of freshwater murrel, Channa punctatus (Bloch 1793) from lotic and lentic environments. World Journal of Fish and Marine Sciences 5(2): 233-238.

Steel RGD, Torrie JH. 1993. Prinsip dan Prosedur Statistika: Suatu Pendekatan Biometrik. Terjemahan: Bambang Sumantri. Jakarta (ID): Gramedia Utama. Suseno SH, Rizkon AK, Jacoeb AM, Nurjanah, Supinah P. 2020. Ekstraksi dry rendering dan karakterisasi minyak ikan patin (Pangasius sp.) hasil samping industri filet di lampung . Jurnal Pengolahan Hasil Perikanan Indonesia. 23(1): 38-46.

Udani K, Barry WR. 2013. High potency fish oil supplement improves omega-3 fatty acid status in health adults: an open-label study using a web-based, virtual platform. Nutrition Journal. 112(12): 1-5.

Velasquez SF, Chan MA, Abisado RG, Traifalgar RFN, Tayamen MM, Maliwat GCF, Ragaza JA. 2016. Dietary Spirulina (Arthrospira platensis) replacement enhances performance of juvenile nile tilapia (Oreochromis niloticus). Journal of Applied Phycology. 28(2): 1023-1030. 
Viera, V.A., A.W. Hilsdorf. and R.G. Moreira. 2012. The fatty acids profile and energetic substrates of two nile tilapia (Oreochromis niloticus Linnaeus) strains, Re-stirling and chitralada, and their hybrid. Aquaculture Research. 43:565-576.
Widyastuti, Y.R. 2008.Peningkatan Produksi Air Tawar melalui Budidaya Ikan Sistem Akuaponik. Prosiding Seminar Nasional Limnologi IV LIPI. Bogor : 62-73. 